\title{
Characteristics of the Ascophyllum nodosum stands and their associated diversity along the coast of Brittany, France
}

\author{
CLAIRE GOLLETY ${ }^{1,2,3}$, ERIC THIEBAUT ${ }^{1,2}$ AND DOMINIQUE DAVOULT ${ }^{1,2}$ \\ ${ }^{1}$ UPMC Université de Paris 6, UMR 7144, Station Biologique de Roscoff, 29682, Roscoff, France, ${ }^{2}$ CNRS, UMR 7144 , Station \\ Biologique de Roscoff, 29682, Roscoff, France, ${ }^{3}$ Department of Zoology, University College Dublin, Belfield, Dublin 4, Ireland
}

\begin{abstract}
The present study aimed at estimating the characteristics of the Ascophyllum nodosum stands along the coast of Brittany, France. Although both an ecologically and economically important macroalga on sheltered rocky shores of the North Atlantic, no study has simultaneously dealt with the variability of the densities, lengths and biomasses of A. nodosum together with a description of its associated algal and animal diversity. There were significant differences in mean lengths and variations in the length-population structures between sites. However, the biomasses and densities showed no significant differences. The biomasses are amongst the highest ones estimated over the entire species distribution. The algal and animal assemblages were typical of A. nodosum zones, but only the identity composition of the algal communities seemed to reflect site differences in environmental forces. The biomasses measured in the present study should help improve future macroalgae biomass and metabolism estimates on regional or global scales. Finally, the data will provide a reference state for future studies on the responses of fucoid canopies to environmental changes.
\end{abstract}

Keywords: Ascophyllum nodosum, biomass, density, lengths, rocky shores, species richness

Submitted 17 July 2009; accepted 5 April 2010; first published online 17 June 2010

\section{INTRDDUCTIDN}

Reviews that estimate global or regional coastal metabolism and carbon fluxes due to primary producers (e.g. Smith, 1981; Gattuso et al., 1998; Middelburg et al., 2005) need to use first-hand biomass and productivity data of the different primary producers. However, data on macroalgae biomass are still few and consequently result in biased estimates: in the best case scenarios, Smith (1981) or Gattuso et al. (1998) use an estimate of the surface cover area of macroalgae as an underestimate of the biomass per unit area that is then used in several subsequent reviews (Middelburg et al., 2005). In the worst case scenario, Gazeau et al. (2004) do not take into account primary production from macrophytes (seagrasses and macroalgae) in their regional scale estimates due to the lack of data on the production and surface area covered by macrophytes in Europe. The inadequacy of using percentage cover as a proxy for biomass (Masterson et al., 2008), and the lack of biomass estimates both compel for firsthand estimates of the dominant macroalgae of a region.

The fucale Ascophyllum nodosum (L.) Le Jolis is characteristic of the mid-intertidal zones of North Atlantic temperate sheltered rocky shores. This canopy-forming alga has a major role in the functioning of the zone. It acts as a foundation species (sensu Bruno \& Bertness, 2001) by regulating the community composition and richness of the associated

Corresponding author:

C. Gollety

Email: claire.gollety@ucd.ie algal and animal assemblages (Bertness et al., 1999; Jenkins et al., 1999a). In addition, it is responsible for the major carbon fluxes of the zone (Golléty et al., 2008). This species is also economically important, since $A$. nodosum is being harvested in several countries of its distribution for its value as a fertilizer, animal fodder and its good alginic acid extraction yields. Recently, a long-term decline of fucoid canopies including $A$. nodosum has been reported in several European locations (including Brittany) in response to various climate change-driven factors (Le Roux, 2005; Airoldi \& Beck, 2007; Davies et al., 2007). The loss of A. nodosum stands often involves the replacement of the canopy with filter-feeders, thus altering the carbon flows within the ecosystem.

In France, the distribution of this macroalga is concentrated along the coasts of Brittany, which is a major site for $A$. nodosum harvesting along the European rocky shores (Airoldi \& Beck, 2007). In this area, the most recent biomass estimates, around 13,000 tons, have been calculated on the basis of the harvested amounts of algae received by the processing industries and are not easily available to the scientific community (Arzel \& Véron, 2005). Yet, no studies have attempted to estimate the variability of the densities, lengths and biomasses of A. nodosum along this region. Given the long harvesting history taking place in Brittany, the proportion of canopy-covered shores along these coasts and the important functional role of this canopy for the community, it is even more surprising that such a study has never been performed in this area. The variability of the A. nodosum density and length over such an area could also affect the distribution of the associated algal and animal assemblages (Cervin et al., 2004) and the ecosystem functioning. The present study thus 
aimed at: (1) estimating the variability of the A. nodosum lengths, biomasses and densities at the meso-scale (i.e. $\mathrm{km}$ to 100 s of $\mathrm{km}$ ); and (2) describing the animal and algal assemblages associated with the zone and their variability at the local scale (i.e. sampling site) and meso-scale. It will then provide a reference state for future studies on primary production estimates at regional scales and on the responses of rocky shores communities to environmental changes.

\section{MATERIALS AND METHDDS}

The shores of Penmarc'h, Molène, Coulouarn, and Bréhat are distributed clockwise along a stretch of the Brittany coast (France) over $200 \mathrm{~km}$ long (Figure 1). The intertidal zone at Penmarc'h consists of large sheltered bedrock with large boulders. Because of the very weak slope of this shore, the Ascophyllum nodosum zone extends over several $100 \mathrm{~m}$. The study site at Molène is located in the northern part of the Molène Island over a steeper and slightly less sheltered zone than Penmarc'h but also dominated by large granite boulders. The study site at Coulouarn is located on a small island made up of smaller boulders on which the A. nodosum zone only spreads over a few metres. This is probably the least sheltered of the five locations. Finally, the last two study sites are located on the Island of Bréhat, respectively on the west and the east coasts of the island. These two sites were the most sheltered ones, so much that the A. nodosum zone is found on a rocky zone slightly covered with fine sand and even some mud on the east coast. These five shores were chosen because they are representatives of the landscape variability of sheltered rocky shores along the Brittany coast. They are also shores where $A$. nodosum harvesting often takes place although we were careful in choosing study sites where no harvesting had taken place prior to the study.

Sampling was performed in winter so that any influence of ongoing recruitment or post-recruitment mortality did not bias the composition of the algal and animal assemblages (Warner, 1984). Sampling took place in early February 2005 on twelve $0.5 \times 0.5 \mathrm{~m}$ quadrats distributed evenly on both sides of a $10 \mathrm{~m}$ transect line. Care was taken to place the transect perpendicularly to the tidal gradient and in the middle of the vertical distribution of the canopy zone of each site, so that the presence of other canopy species could not be accounted for by border effects with the neighbouring macroalgae belts. Traditionally, an Ascophyllum nodosum individual is defined as the assemblage of fronds or shoots arising directly or indirectly from a common holdfast (Baardseth, 1955). However, holdfast fragmentation or holdfast formation from several zygotes is also possible (Aberg, 1989). The total length and maximum circumference of each A. nodosum was thus measured on individual plants, defined as all the shoots originating from touching holdfasts. On each quadrat, identification of all the macroalgae and macrofauna was recorded to the lowest possible taxon identifiable in the field. As this implied identification of different taxonomic levels, the algal and animal diversity are expressed as numbers of taxa per quadrat (taxa.quadrat ${ }^{-1}$ ). Densities (ind. $\mathrm{m}^{-2}$ ) were also estimated for each animal taxon, except for the colonial organisms and the polychaete Spirorbis sp., for which both densities and percentage cover are very difficult to obtain on three-dimensional substrates.

Ascophyllum nodosum density (ind. $\mathrm{m}^{-2}$ ) and biomass $\left(\mathrm{kg}_{\mathrm{DW}} \cdot \mathrm{m}^{-2}\right)$ for each site were calculated from the mean number of $A$. nodosum individuals per quadrat and the mean $A$. nodosum dry weight per quadrat respectively. The $A$. nodosum dry weight of each quadrat is the sum of each $A$. nodosum plant dry weight ( $D W$, expressed as $\left.\mathrm{g}_{D W}\right)$, estimated using the following allometric relationship (Aberg, 1990):

$$
D W=0.057 \cdot\left(l c^{2}\right)^{0.790}
$$

where $l$ is the total length and $c$ the maximum circumference of a single plant. A preliminary study, based on $77 \mathrm{~A}$. nodosum plants collected at four different sites along the Brittany coastline, confirmed that this relationship could be used in our study. Indeed, there was a significant correlation between the estimated $D W(x)$ based on the above relationship and
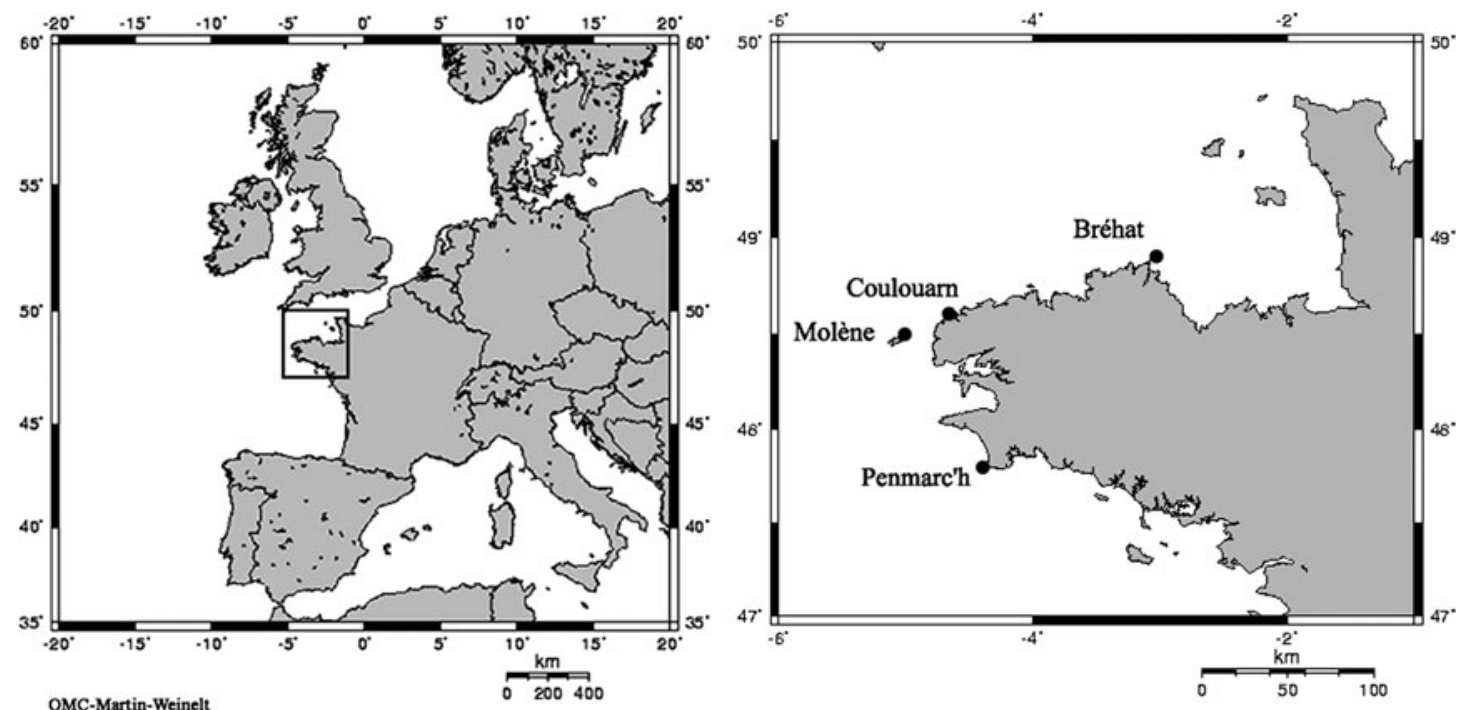

Fig. 1. Location of the five study sites along the coast of Brittany, France. The sites of Penmarc'h and Coulouarn are located on the continent, while the two Bréhat sites are on the west and east coast of the Bréhat Island $1 \mathrm{~km}$ away from the continent and the Molène site is on the north-eastern coast of the Molène Island over $20 \mathrm{~km}$ away from the continent. 
the measured $D W(y)(\mathrm{r}=0.981, \mathrm{~N}=77, P<0.001)$, which allowed calculating the following linear regression: $y=$ $0.986 \cdot x-1.78$. The intercept of this regression was not significantly different from o (Student's $t$-test: $t=0.32, P=0.375$ ) while the slope was not significantly different from 1 (Student's $t$-test: $t=1.27, P=0.104$ ). Therefore, there is no significant difference between the measured and the estimated $D W$. The population structure of $A$. nodosum lengths was assessed at each site by establishing length-frequency histograms of the number of individuals per length-classes of $10 \mathrm{~cm}$ sizes smoothed using third degree weighted moving averages (Legendre \& Legendre, 1998). We compared how the percentage of fronds from the $10 \mathrm{~cm}$ size-classes was distributed among three groups of length-classes: (1) fronds below $20 \mathrm{~cm}$, which is the French legal length for harvesting A. nodosum; (2) fronds above $70 \mathrm{~cm}$, which is the mean length measured over the entire study; and (3) fronds between $20 \mathrm{~cm}$ and $70 \mathrm{~cm}$.

Because of the small sample size (12 quadrats per site), most of our data lacked the normality and homoscedasticity required to perform ANOVAs. Significant differences between $A$. nodosum lengths, biomasses and densities, between mean numbers of algal or animal taxa and between mean numbers of animal densities were thus tested using Kruskal-Wallis tests $\left(\mathrm{H}_{\mathrm{c}}\right.$, the value corrected for tied ranks, SSI SYSTAT 11 software, SYSTAT Software, Inc., Richmond, CA, USA). Post hoc tests (equivalent to the Student-Newman-Keuls test of the ANOVA; Scherrer, 1984) were also performed when needed.

In order to test for any algal and animal taxonomic composition and density differences between the assemblages of each site, cluster analyses based on the Bray-Curtis similarity index (Clarke \& Warwick, 2001) were performed on the presence/absence data of both the algal and animal diversity and on the animal abundances (PRIMER v6.1.6 software; Clarke \& Gorley, 2001). The differentiation between groups was tested using a 'similarity profile' permutation test (SIMPROF test given in PRIMER v6.1.6). The analyses were performed after elimination of the rare taxa, i.e. present in only one quadrat for the two qualitative analyses and having only one individual for the quantitative analysis. For the interpretation of these analyses, we first looked at taxa exclusively present at one or several sites from those that were ubiquitous. Then, we considered their 'occurrence frequency' depending on whether taxa were present at few or many quadrats within a given site.

\section{RESULTS}

\section{Ascophyllum nodosum}

Mean ( \pm standard deviation, SD) individual lengths measured $56 \pm 28 \mathrm{~cm}$ at Coulouarn, $64 \pm 41 \mathrm{~cm}$ at Bréhat west, $70 \pm$ $46 \mathrm{~cm}$ at Bréhat east, $79 \pm 36 \mathrm{~cm}$ at Molène and $88 \pm 53 \mathrm{~cm}$ at Penmarc'h (Figure 2A). Densities were $14 \pm 9.3$ ind. $^{-2}$ in Bréhat east, $16 \pm 8.4$ ind. $\mathrm{m}^{-2}$ in Penmarc'h, $21 \pm$ 4.3 ind. $\mathrm{m}^{-2}$ in Molène, $21 \pm 19.7$ ind. $\mathrm{m}^{-2}$ in Coulouarn, $24 \pm 9.8$ ind. $\mathrm{m}^{-2}$ in Bréhat west (Figure $2 \mathrm{~B}$ ). Biomasses were $2.5 \pm 1.99 \mathrm{~kg} \mathrm{DW} \cdot \mathrm{m}^{-2}$ in Bréhat east, $2.6 \pm 1.82 \mathrm{~kg}_{\mathrm{DW}} \cdot \mathrm{m}^{-2}$ in Penmarc'h, $2.7 \pm 0.98 \mathrm{~kg}$ Dw.m ${ }^{-2}$ in Molène, $2.9 \pm$ $2.42 \mathrm{~kg} \mathrm{DW}_{\mathrm{DW}} \cdot \mathrm{m}^{-2}$ in Coulouarn and $3.7 \pm 2.47 \mathrm{~kg}$ DW. $\mathrm{m}^{-2}$ in Bréhat west (Figure $2 \mathrm{C}$ ). Individual lengths were significantly
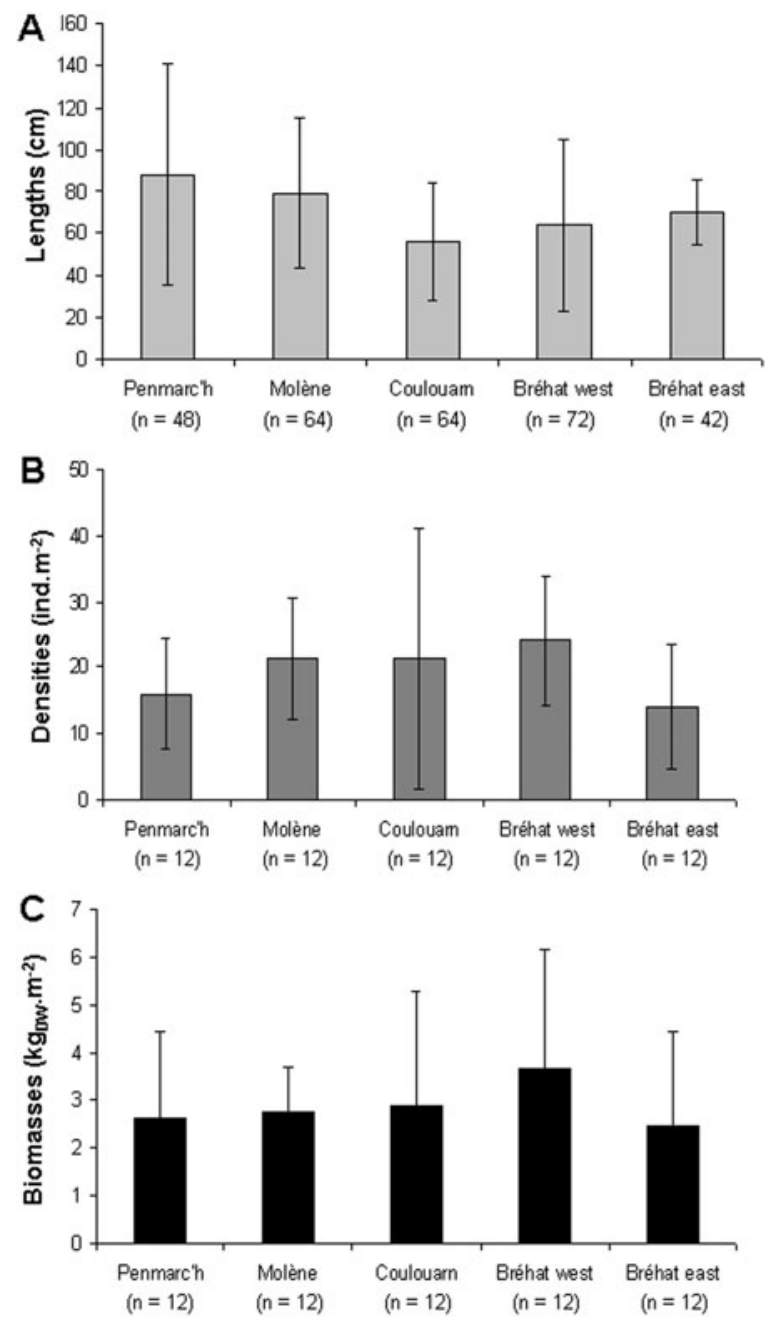

Fig. 2. Mean ( \pm standard deviation) lengths (A), densities (B) and biomasses (C) of the Ascophyllum nodosum plants sampled during the study. Below the site names are given the number of $A$. nodosum individuals, for lengths, and quadrats, for densities and biomasses, used to estimate mean values.

lower at Coulouarn than at Penmarc'h and Molène only $(H c=19.718, P<0.001, \mathrm{~N}=290)$. On the contrary, the biomasses and densities showed no significant differences (biomass: $H c=2.605, P=0.626, \quad \mathrm{~N}=60$; density: $H c=$ $8.326, P=0.080, \mathrm{~N}=60$ ). The class subdivision of the population structure showed that the majority of fronds measured between $20 \mathrm{~cm}$ and $70 \mathrm{~cm}$ in Coulouarn, Bréhat west and Bréhat east while it measured over $70 \mathrm{~cm}$ in Penmarc'h and Molène (Table 1; Figure 3).

Table 1. Percentage of fronds grouped below $20 \mathrm{~cm}$, which is the French legal length for hand harvesting, above $70 \mathrm{~cm}$, which is the mean length measured in the present study, and between $20 \mathrm{~cm}$ et $70 \mathrm{~cm}$.

\begin{tabular}{lcll}
\hline Sites & \% $<\mathbf{2 0} \mathbf{~ c m}$ & $\mathbf{2 0} \mathbf{~ c m}<\%<70 \mathbf{~ c m}$ & $\%>70 \mathbf{~ c m}$ \\
\hline Penmarc'h & 8.3 & 33.8 & 57.9 \\
Molène & 4.4 & 36.6 & 59.0 \\
Coulouarn & 7.2 & 66.0 & 26.8 \\
Bréhat west & 13.1 & 49.9 & 37.0 \\
Bréhat east & 14.1 & 44.7 & 41.2 \\
\hline
\end{tabular}




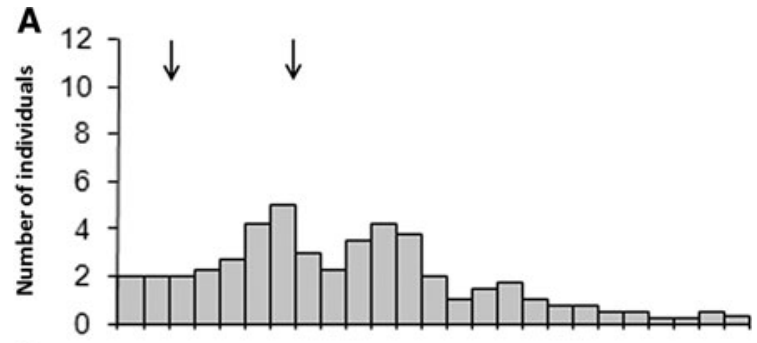

B
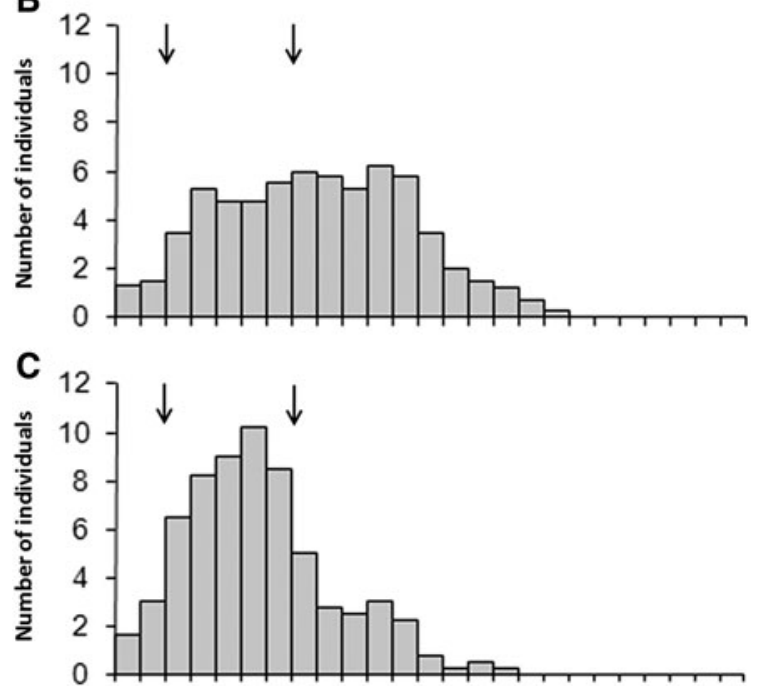

D
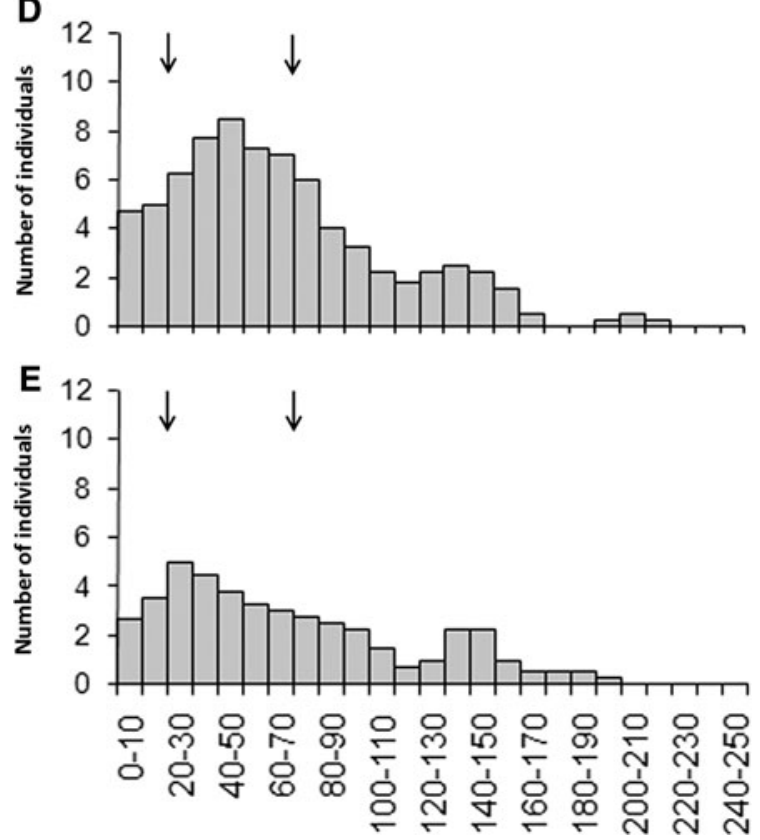

Fig. 3. Ascophyllum nodosum length-frequency histograms using third degree weighted moving averages over $10 \mathrm{~cm}$ size-classes at Penmarc'h (A), Molène (B), Coulouarn (C), Bréhat west (D) and Bréhat east (E). The size-classes are closed on the lower limit and opened on the higher limit. The arrows on the histograms indicate the $20 \mathrm{~cm}$ limit, which is the French legal length for hand harvesting, and the $70 \mathrm{~cm}$ limit, which is the mean length measured in the present study.

\section{Algal and animal diversity}

\section{ALGAL DIVERSITY}

A total of 21 taxa were identified amongst the five sites (Table 2). The algal richness was significantly lower at
Coulouarn than at all the other sites as well as significantly lower at Bréhat east than at Penmarc'h and Molène (Table 3) $(H c=12.481, P=0.014, \mathrm{~N}=60)$.

The cluster analysis based on the algal data was performed on a 57 quadrats $\times 18$ taxa matrix after elimination of the uncommon taxa Calliblepharis sp., Chondracanthus acicularis and Polyides sp. and the removal of three quadrats that had no taxon present. The dendrogram resulted in the significant differentiation $(\pi=1.98, P=0.018)$ between the group A, which isolated 10 of the 11 Bréhat east quadrats together with one-third of the Bréhat west quadrats in spite of some intragroup heterogeneity (similarity $=37.7 \%$ ), and the group B (similarity $=39.2 \%$ ), which included all the remaining quadrats (Figure 4). Within the group B, the differentiation between the group $B_{1}$ (similarity $=44.6 \%$ ) and the group B2 (similarity $=44.1 \%)$ was not significant $(\pi=2.03$, $P=0.064$ ) (Figure 4).

\section{ANIMAL DIVERSITY}

A total of 29 taxa were identified amongst the five sites (Table 4). There were no significant differences in the number of animal taxa between sites (Table 3) $(H c=9.365$, $P=0.053, \mathrm{~N}=60$ ). The cluster analysis performed on the qualitative data was carried out on a 60 quadrats $\times 21$ taxa matrix after elimination of the uncommon taxa Anemonia viridis, Achantochitona sp., Chthamalus sp., Lipophrys pholis, Botryllus schlosseri, Bunodactis verrucosa, Dendrodoa grossularia and Flustrellidra hispida. The resulting dendrogram showed that no faunal assemblages could be significantly differentiated by the SIMPROF test; there is thus no overall structuring between sites (Figure 5).

Among the 29 animal taxa, 20 could be enumerated. Their mean densities $( \pm S D)$ at Molène $\left(30 \pm 15.8\right.$ ind. $\left.\mathrm{m}^{-2}\right)$ were significantly lower than at the other sites while those at Penmarc'h (114 \pm 36.2 ind. $\mathrm{m}^{-2}$ ) were significantly higher than at the two Bréhat sites (Table 3) $(H c=24.268, P<$ $0.001, \mathrm{~N}=60$ ). The cluster analysis performed on the quantitative data was carried out on a 60 quadrats $\times 19$ taxa matrix after elimination of the rare taxon Achantochitona sp. Again, the dendrogram showed no structuring between sites (data not shown).

\section{DISCUSSIDN}

\section{Ascophyllum nodosum}

Few Ascophyllum nodosum lengths and densities estimates have been reported so far in the literature, essentially due to the difficulty to define $A$. nodosum individuals. The mean $( \pm \mathrm{SD})$ A. nodosum lengths estimated to $69 \pm 26.3 \mathrm{~cm}$ and $86 \pm 2.7 \mathrm{~cm}$ in two Irish sites (Kelly et al., 2001) and to $74.5 \pm 27.6 \mathrm{~cm}$ in New Brunswick, Canada (Ugarte et al., 2006) are in the same range as measured in the present study. Densities estimated to 50 ind. $\mathrm{m}^{-2}$ in Maine, USA (Bertness et al., 1999) were two to over three times higher than those measured in the present study. By contrast, the biomasses calculated in the present study along the Brittany coasts are comparable to the highest ones measured along the A. nodosum distribution (Table 5).

Differences in population structures could be observed between sites, going from a broad distribution over a wide range of lengths to a skewed distribution towards relatively 
Table 2. Presence of algal taxa at each site.

\begin{tabular}{|c|c|c|c|c|c|}
\hline \multirow[t]{2}{*}{ Algal taxon } & \multicolumn{5}{|l|}{ Site } \\
\hline & Penmarc'h & Molène & Coulouarn & Bréhat west & Bréhat east \\
\hline \multicolumn{6}{|l|}{ Phaeophyceae } \\
\hline Fucus serratus & + & + & + & & \\
\hline Fucus vesiculosus & + & & & + & + \\
\hline \multicolumn{6}{|l|}{ Chlorophyceae } \\
\hline Ulva sp. & & + & & + & + \\
\hline Ulva sp. form Enteromorpha & & & & + & \\
\hline Cladophora rupestris & + & + & & & \\
\hline \multicolumn{6}{|l|}{ Rhodophyceae } \\
\hline Antithamnionella elegans & & & & + & \\
\hline Calliblepharis sp. & & + & & & \\
\hline Chondracanthus acicularis & & & & + & \\
\hline Chondrus crispus & & + & & & + \\
\hline Corallina elongata & + & + & & & \\
\hline Gigartina sp. & & + & & & \\
\hline Heterosiphonia sp. & & + & & & \\
\hline Hildenbrandia rubra & + & + & + & + & + \\
\hline Lomentaria articulata & + & + & & & \\
\hline Mastocarpus stellatus & & & + & + & + \\
\hline Phymatolithon lenormandii & + & + & + & + & + \\
\hline Vertebrata lanosa & + & + & + & + & + \\
\hline Rhodothamniella floridula & & & & + & + \\
\hline Catenella caespitosa & & & + & + & \\
\hline Polyides sp. & & + & & & \\
\hline
\end{tabular}

+ , presence.

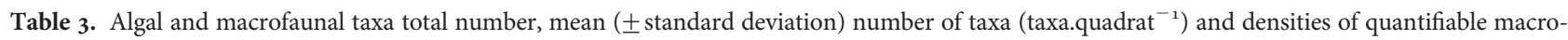
faunal taxa (ind. $\mathrm{m}^{-2}$ ) at each site.

\begin{tabular}{|c|c|c|c|c|c|c|c|c|}
\hline \multirow[t]{2}{*}{ Site } & \multicolumn{3}{|c|}{ Algae } & \multicolumn{5}{|c|}{ Macrofauna } \\
\hline & $\mathbf{N}$ & Mean number & SD & $\mathbf{N}$ & Mean number & SD & Mean density & SD \\
\hline Penmarc'h & 8 & $4 \cdot 3$ & 1.07 & 13 & 4.6 & 1.44 & 114 & 36.2 \\
\hline Molène & 13 & 5.2 & 2.08 & 12 & 4.5 & 0.80 & 30 & 15.8 \\
\hline Coulouarn & 6 & 2.8 & 1.36 & 17 & 5.5 & 1.98 & 85 & 51.2 \\
\hline Bréhat west & 12 & 3.8 & 1.42 & 11 & 4.1 & 1.44 & 89 & 53.4 \\
\hline Bréhat east & 9 & 3.5 & 1.24 & 13 & 6.2 & 2.21 & 84 & 45.2 \\
\hline
\end{tabular}

$\mathrm{N}$, total number; SD, standard deviation.

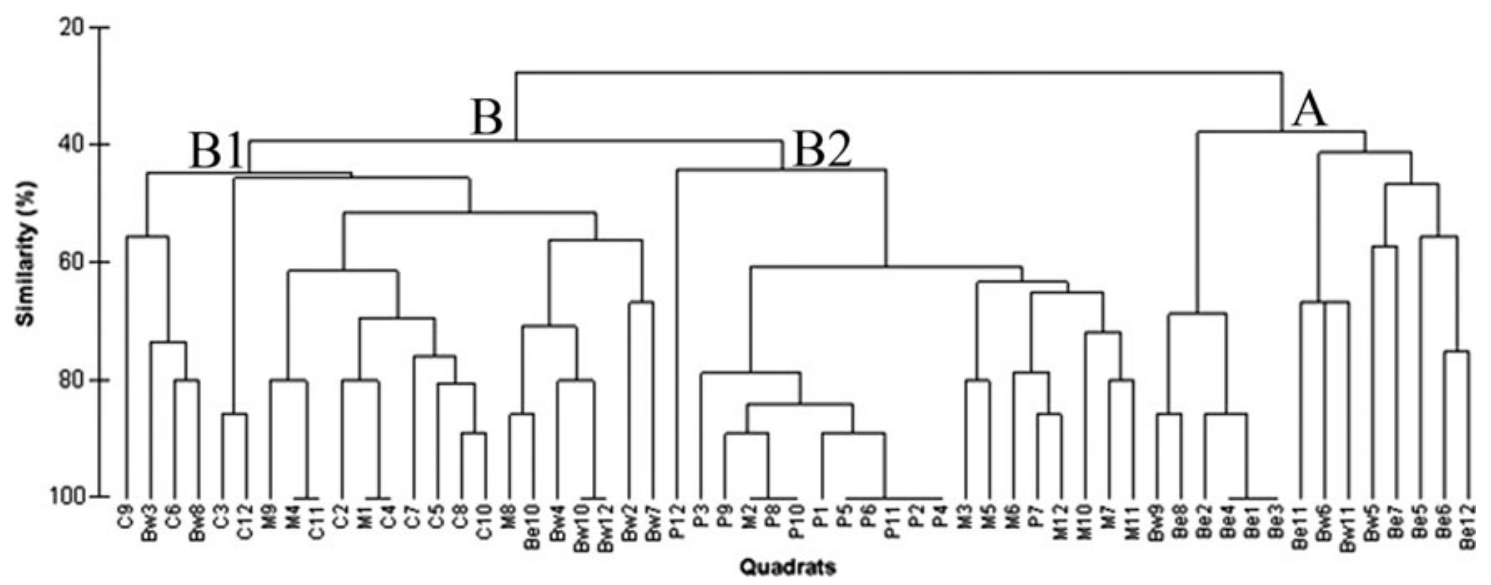

Fig. 4. Dendrogram resulting from the cluster analysis performed on the macroalgal presence or absence data on a 57 quadrats $\times 18$ taxa matrix using the $\mathrm{S}_{17}$ Bray-Curtis similarity index at the sites of Penmarc'h (P), Molène (M), Coulouarn (C), Bréhat west (Bw), and Bréhat east (Be). 
Table 4. Presence and numbers when possible of macrofaunal taxa at each site.

\begin{tabular}{|c|c|c|c|c|c|}
\hline \multirow[t]{2}{*}{ Animal taxon } & \multicolumn{5}{|l|}{ Site } \\
\hline & Penmarc'h & Molène & Coulouarn & $\begin{array}{l}\text { Bréhat } \\
\text { west }\end{array}$ & $\begin{array}{l}\text { Bréhat } \\
\text { east }\end{array}$ \\
\hline \multicolumn{6}{|l|}{ Porifera } \\
\hline Grantia compressa & & + & + & & \\
\hline $\begin{array}{l}\text { Halichondria } \\
\text { panicea }\end{array}$ & & + & + & & \\
\hline $\begin{array}{l}\text { Hymeniacidon } \\
\text { sanguinea }\end{array}$ & & + & + & & + \\
\hline \multicolumn{6}{|l|}{ Cnidaria } \\
\hline Dynamena pumila & & + & + & & \\
\hline $\begin{array}{l}\text { other hydroid } \\
\text { Anemonia viridis }\end{array}$ & + & + & 2 & & + \\
\hline Actinia equina & 1 & 12 & 1 & & 8 \\
\hline $\begin{array}{l}\text { Bunodactis verrucosa } \\
\text { other anemone }\end{array}$ & & 2 & 3 & & \\
\hline Polychaeta & & & & & \\
\hline $\begin{array}{l}\text { Spirorbis sp. } \\
\text { Crustacea }\end{array}$ & + & + & + & + & + \\
\hline Balanus perforatus & & & 4 & 1 & 30 \\
\hline Chthamalus sp. & & & 2 & & \\
\hline $\begin{array}{l}\text { Semibalanus } \\
\text { balanoides }\end{array}$ & & & & 3 & \\
\hline amphipod & 1 & & & 1 & 6 \\
\hline Pagurus bernhardus & 4 & & & & \\
\hline $\begin{array}{l}\text { Carcinus maenas } \\
\text { Gastropoda }\end{array}$ & & 1 & & & 2 \\
\hline Achantochitona sp. & & & & & 1 \\
\hline Patella vulgata & 26 & 53 & 95 & 6 & 51 \\
\hline Littorina littorea & 1 & & & 2 & \\
\hline Littorina obtusata & 193 & 16 & 35 & 147 & 113 \\
\hline Gibbula cineraria & 2 & & & & \\
\hline Gibbula pennanti & 2 & & & 1 & \\
\hline Gibbula umbilicalis & 110 & 6 & 110 & 13 & 23 \\
\hline Osilinus lineatus & & & & 36 & 15 \\
\hline $\begin{array}{l}\text { Nucella lapillus } \\
\text { Bryozoa }\end{array}$ & 1 & & 2 & 2 & \\
\hline $\begin{array}{l}\text { Flustrellidra hispida } \\
\text { Chordata }\end{array}$ & & & + & & \\
\hline Botryllus schlosseri & & & + & & \\
\hline $\begin{array}{l}\text { Dendrodoa grossularia } \\
\text { Fish }\end{array}$ & & & + & & \\
\hline Blennius pholis & & & & & 2 \\
\hline
\end{tabular}

+ , presence.
Table 5. Biomass $\left(\mathrm{kg}_{\mathrm{DW}} \cdot \mathrm{m}^{-2}\right)$, measured using both direct and indirect methods, of Ascophyllum nodosum stands along the distribution of the species.

\begin{tabular}{|c|c|c|c|}
\hline \multicolumn{2}{|l|}{ Biomass } & \multirow[t]{2}{*}{ Location } & \multirow[t]{2}{*}{ Author } \\
\hline Mean & SD & & \\
\hline 2.5 & 1.99 & Bréhat east, France & This study \\
\hline 3.7 & 2.47 & Bréhat west, France & This study \\
\hline 0.6 & 0.33 & New Hampshire, USA & (Chock \& Mathieson, 1983) \\
\hline $1.04-2.03$ & - & Iceland & (Munda, 1987) \\
\hline 1.6 & 0.43 & Northern Spain & (Soneira \& Niell, 1975) \\
\hline 3.0 & 0.82 & Northern Spain & (Soneira \& Niell, 1975) \\
\hline 3 & - & Nova Scotia, Canada & (Cousens, 1984) \\
\hline $2.85-9.7$ & - & Maine, USA & (Vadas et al., 2004) \\
\hline 4.5 & 0.39 & $\begin{array}{l}\text { Northern Brittany, } \\
\text { France }\end{array}$ & $\begin{array}{l}\text { (estimated from } \\
\text { Guillaumont et al., 1993; } \\
\text { Arzel et al., 2001) }\end{array}$ \\
\hline
\end{tabular}

$\mathrm{SD}$, standard deviation.

long lengths. Both Bréhat sites displayed the greatest percentage of short lengths (i.e. fronds below $20 \mathrm{~cm}$ ) and equal percentages of fronds over the rest of the distribution (i.e. fronds between $20 \mathrm{~cm}$ and $70 \mathrm{~cm}$ and above $70 \mathrm{~cm}$ ) whereas Coulouarn was dominated by fronds between $20 \mathrm{~cm}$ and $70 \mathrm{~cm}$. Finally, Molène, and even more so Penmarc'h, displayed a skewed distribution towards long lengths (i.e. above $70 \mathrm{~cm}$ ). These different population structures reveal the important length heterogeneity that can be found among $A$. nodosum stands. Indeed, $A$. nodosum length can greatly vary either within or between sites, both at the sampling and at the site scale, due to the variability in: (1) grazing pressure (e.g. Viejo \& Aberg, 2003); (2) environmental forces such as wave action (e.g. Keser et al., 2005); or (3) harvesting impact (e.g. Ang et al., 1996). However, in our case, neither the differences in site exposure nor in grazer densities seem to support the observed population structures. More detailed information on the variability of these factors at the local scale as well as long term differences in recruitment intensity or changes in the survival of existing plants, which has proven to influence population growth rates (Aberg, 1992), could potentially explain the observed differences in population structures (Davies et al., 2007). Unfortunately, these data are not available at our study sites or only available at the scale

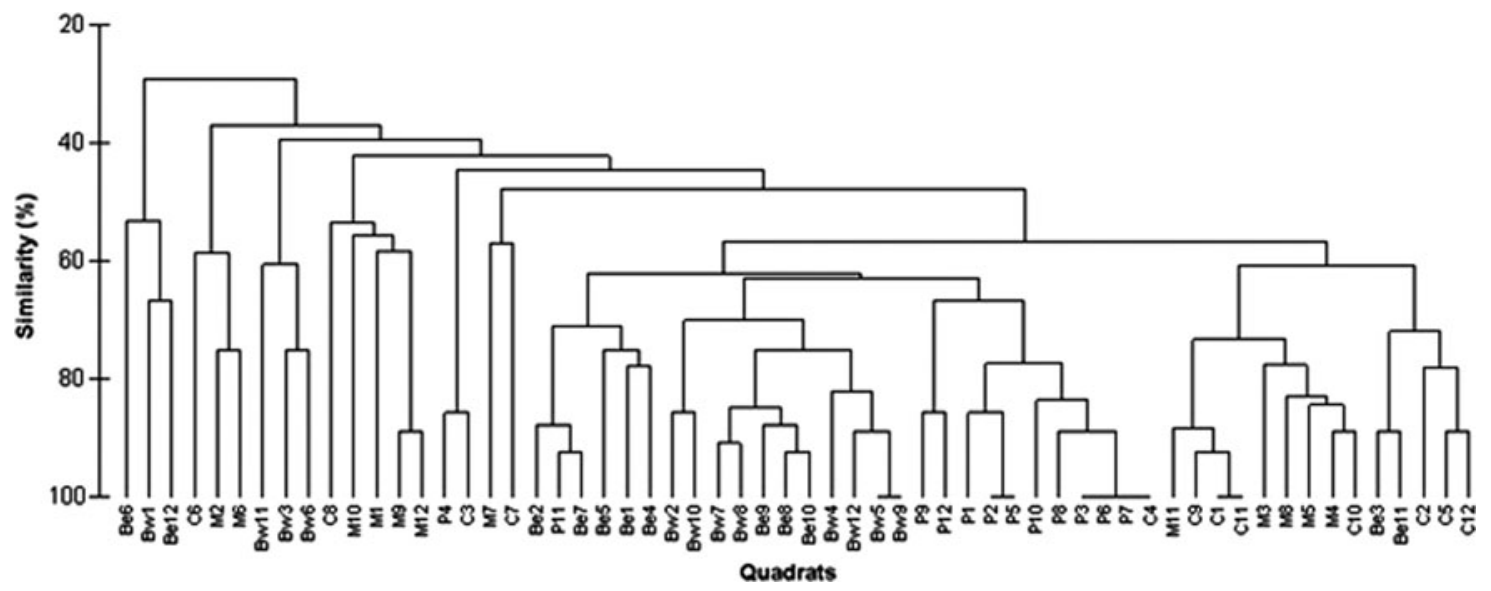

Fig. 5. Dendrogram resulting from the cluster analysis performed on the macrofauna presence or absence data on a 60 quadrats $\times 21$ taxa matrix using the $S_{17}$ Bray-Curtis similarity index at the sites of Penmarc'h (P), Molène (M), Coulouarn (C), Bréhat west (Bw), and Bréhat east (Be). 
of the Brittany coast in the case of the wave regimes. In spite of these differences, the absence of significant differences in biomass (Figure $2 \mathrm{C}$ ) suggests that the stimulated growth and production of new laterals on cut or basal shoots compensated for the lost biomass (Lazo \& Chapman, 1996; Ugarte et al., 2006).

\section{Algal and animal diversity}

The algal and animal community observed in the present study form a common assemblage typical of Ascophyllum nodosum zones. This assemblage is essentially dominated by the algae Hildenbrandia rubra, Phymatolithon lenormandii, Vertebrata lanosa and Ulva sp., and the invertebrates Carcinus maenas, Dynamena pumila, Gibbula umbilicalis, Nucella lapillus, Littorina obtusata, Patella vulgata and Spirorbis sp., also characteristic of most A. nodosum zones of other geographical areas (e.g. Boaden \& Dring, 1980; Connor et al., 1997; Kelly et al., 2001; Cervin et al., 2004).

\section{ALGAL DIVERSITY}

The significant difference in the number of algal taxa suggests a heterogeneous distribution of the taxonomic diversity at the meso-scale. Indeed, Coulouarn displayed a significantly lower mean number of taxa than at all the other sites due to the absence of any green taxa and that of the two-thirds of the red taxa identified over the study. Bréhat west had a significantly lower mean number of taxa than Penmarc'h and Molène due to the overall lower occurrence frequencies at the sampling scale. The structuring between sites evidenced by the cluster analysis reveals a homogeneous distribution of the algal identity composition at the sampling scale but with a heterogeneous distribution between sites. In particular, the two groups evidenced by the dendrogram discriminated sites essentially upon the presence of either Fucus vesiculosus, almost exclusively present in the Bréhat sites from the A group, or Fucus serratus, frequently present on the other sites and absent from Bréhat. The Bréhat sites exhibited high biomasses distributed over short individuals, probably enabling more light to reach the substrate. This could allow F. vesiculosus, apparently more competitive among sparser $A$. nodosum canopies, to develop faster than $F$. serratus (Jenkins et al., 1999b). On the contrary, F. serratus will take over under the more developed or dense A. nodosum canopies of Penmarc'h, Molène and Coulouarn.

\section{ANIMAL DIVERSITY}

Contrary to the algal richness, there is an absence of significant difference in the number of taxa, which suggests a homogeneous distribution of the animal taxonomic richness at the meso-scale. The absence of strong structuring between sites evidenced by the cluster analysis reveals on the contrary a heterogeneous distribution of the animal identity composition at the sampling scale. This heterogeneity at the sampling scale prevents characterizing the animal identity composition at the meso-scale.

The significant difference in animal densities suggests a heterogeneous distribution of the overall densities at the meso-scale. The observed site ranking, resulting from significantly lower densities at Molène than at the other sites and significantly higher densities at Penmarc'h than at Bréhat west and east, is mostly due to density differences of Littorina obtusata and Gibbula umbilicalis, the most abundant taxa of the
Ascophyllum nodosum zone studied here. Indeed, these two taxa showed lowest densities at Molène, intermediate at the two Bréhat sites and highest at Penmarc'h. In addition, excluding the densities of L. obtusata, G. umbilicalis, Patella vulgata, Osilinus lineatus and Balanus perforatus from the analysis resulted in no significant difference between sites $(H c=4.679, P=0.322, \mathrm{~N}=60)$. This emphasizes how $A$. nodosum zones are characterized by the dominance of a few typical macrofaunal taxa. Although the dominance of L. obtusata and G. umbilicalis among A. nodosum stands might seem evident, previous studies have concentrated on the first species only. The A. nodosum zone is recognized as L. obtusata preferred habitat compared to other fucoid zones (e.g. Underwood, 1973) and this species is the dominant periwinkle of most European A. nodosum shores (e.g. Watson \& Norton, 1987; Williams, 1995). On the contrary, the zonation of $G$. umbilicalis has been rarely dealt with (Underwood, 1973) and a wide range of intertidal habitats, more or less covered with macroalgae, seems to suit this prosobranch (Bode et al., 1986; Gaudèncio \& Guerra, 1986; Kendall \& Lewis, 1986). At the sampling scale, the absence of structuring between sites evidenced by the cluster analysis reveals a heterogeneous distribution of the taxonomic densities.

The A. nodosum zone is thus characterized by: (1) a homogeneous taxonomic richness of the macrofaunal assemblage at the meso-scale, typical of these shores; (2) an important assemblage of accessory taxa responsible for a taxonomic composition heterogeneity at the sampling site; (3) a heterogeneous distribution of the overall macrofauna densities at the meso-scale, due to the density differences of the most abundant taxa; and (4) a heterogeneous distribution of the taxonomic densities at the sampling scale due to a great variability in the densities of the accessory taxa.

\section{CONCLUSION}

The present study established that both the algal and animal assemblages are typical of Ascophyllum nodosum zones at the meso-scale studied here. Differences between sites in environmental forces, such as light penetration through the canopy, but probably also wave action and sediment accumulation as observed in the Bréhat sites, and substrate heterogeneity, might explain the major differences in algal diversity. More detailed characteristics of these forces at the local scale would however need to be obtained to validate these hypotheses. The animal assemblage was taxonomically homogeneous at the meso-scale. Yet, the differences in densities of the most abundant taxa could not be accounted for in the present study. A detailed analysis of the zonation and distribution of these species as well as the environmental forces and coastal hydrodynamic differences between sites (Menge et al., 1997) would probably improve our understanding of the regional diversity variations observed in the present study.

The A. nodosum zones studied along the coast of Brittany display comparable mean lengths to previously reported values from other regions over the distribution of the species. Unlike the mean lengths, the estimated biomasses are amongst the highest measured along the species range. The differences in population structures allowed emphasizing the capacity of $A$. nodosum to rapidly compensate for lost biomasses through vegetative growth. Finally, the biomasses estimated at the meso-scale complete the rare estimates 
available for macroalgae in this region. The lack of significant biomass variability at the meso-scale suggests that these data could be used together with regional cartography studies of A. nodosum stands to establish good estimates of the $A$. nodosum biomasses present around Brittany.

\section{ACKNDWLEDGEMENTS}

The authors wish to thank P. Arzel, C. Broudin, C. Daguin-Thiébaut, C. Destombe, C. Engel, F. Gentil, D. Knoch, E. Lacut, L. Lévèque, D. Muths, F. Rigal, I. Smyczynski and M. Voisin for their great help in sampling, N. Simon for her help with algal identification, R. Cousens for sharing his knowledge on the biology of $A$. nodosum, J. Trigui for her help using the PRIMER software, and R. Araújo for collecting and measuring the A. nodosum individuals for the preliminary study on the allometric relationship. This work was part of $\mathrm{PhD}$ thesis of C.G., which was financially supported by the Brittany region.

\section{REFERENCES}

Aberg P. (1989) Distinguishing between genetic individuals in Ascophyllum nodosum populations on the Swedish west coast. British Phycology Journal 24, 183-190.

Aberg P. (1990) Measuring size and choosing category size for a transition matrix study of the seaweed Ascophyllum nodosum. Marine Ecology Progress Series 63, 281-287.

Aberg P. (1992) Size-based demography of the seaweed Ascophyllum nodosum in stochastic environments. Ecology 73, 1488-1501.

Airoldi L. and Beck M.W. (2007) Loss, status and trends for coastal marine habitats of Europe. Oceanography and Marine Biology: an Annual Review 45, 345-405.

Ang P.O., Sharp G.J. and Semple R.E. (1996) Comparison of the structure of populations of Ascophyllum nodosum (Fucales, Phaeophyta) at sites with different harvesting histories. Hydrobiologia 326/327, $179-184$.

Arzel P. and Véron G. (2005) Pêche à pied professionnelle en Iroise Activités halieutiques et activités récréatives dans le cadre d'un espace à protéger: le cas du Parc National de la Mer d'Iroise. Groupe de Recherche AMénagement des Usages des Ressources et des Ecosystèmes marins Littoraux, R-05-2005, 516 p.

Arzel P., Abernot-Le Gac C., Drogou M., Huet J. and Larour M. (2001) Etude des engins de récolte des algues. Rapport Final. Ifremer, oo/2 210 $153 / \mathrm{F}, 85 \mathrm{pp}$.

Baardseth E. (1955) Regrowth of Ascophyllum nodosum after harvesting Report of the Institute for Industrial Research and Standards. Institute for Industrial Research and Standards, Dublin, 66 pp.

Bertness M.D., Leonard G.H., Levine J.M., Schmidt P.R. and Ingraham A.O. (1999) Testing the relative contribution of positive and negative interactions in rocky intertidal communities. Ecology 80, 2711-2726.

Boaden P.J.S. and Dring M.T. (1980) A quantitative evaluation of the effects of Ascophyllum harvesting on the littoral ecosystem. Helgoland Marine Research 33, 700-710.

Bode A., Lombas I. and Anadon N. (1986) Preliminary studies on the reproduction and population dynamics of Monodonta lineata and Gibbula umbilicalis (Mollusca, Gastropoda) on the central coast of Asturias (N. Spain). Hydrobiologia 142, 31-39.
Bruno J.F. and Bertness M.D. (2001) Habitat modification and facilitation in benthic marine communities. In Bertness M.D., Gaines S.D. and Hay M.E. (eds) Marine community ecology. Sunderland, MA: Sinauer Associates, Inc, pp. 201-218.

Cervin G., Lindegarth M., Viejo R.M. and Aberg P. (2004) Effects of small-scale disturbance of canopy and grazing on intertidal assemblages on the Swedish west coast. Journal of Experimental Marine Biology and Ecology 302, 35-49.

Chock J.S. and Mathieson A.C. (1983) Variations of New England seaweed biomass. Botanica Marina 26, 87-97.

Clarke K.R. and Gorley R.N. (2001) Primer (Plymouth Routines In Multivariate Ecological Research). Plymouth: PRIMER-E Ltd.

Clarke K.R. and Warwick R.M. (2001) Changes in marine communities: an approach to statistical analysis and interpretation. Plymouth: PRIMER-E, Ltd.

Connor D.W., Brazier P., Hill T.O. and Northern K.O. (1997) Marine nature conservation review: marine biotope classification for Britain and Ireland. Volume 1. Littoral biotopes. Joint Nature Conservation Committee, No. 229, $362 \mathrm{pp}$

Cousens R. (1984) Estimation of annual production by the intertidal brown alga Ascophyllum nodosum (L.) le Jolis. Botanica Marina 27, 217-227.

Davies A.J., Johnson M.P. and Maggs C.A. (2007) Limpet grazing and loss of Ascophyllum nodosum canopies on decadal time scales. Marine Ecology Progress Series 339, 131-141.

Gattuso J.-P., Frankignoulle M. and Wollast R. (1998) Carbon and carbonate metabolism in coastal aquatic ecosystem. Annual Review of Ecology and Systematics 29, 405-434.

Gaudèncio M.J. and Guerra M.T. (1986) Preliminary observations on Gibbula umbilicalis (da Costa, 1778) on the Portuguese coast. Hydrobiologia 142, 23-30.

Gazeau F., Smith S.V., Gentili B., Frankignoulle M. and Gattuso J.-P. (2004) The European coastal zone: characterization and first assessment of ecosystem metabolism. Estuarine, Coastal and Shelf Science $60,673-674$

Golléty C., Migné A. and Davoult D. (2008) Benthic metabolism on a sheltered rocky shore: role of the canopy in the carbon budget. Journal of Phycology 44, 1146-1153.

Guillaumont B., Callens L. and Dion P. (1993) Spatial distribution and quantification of Fucus species and Ascophyllum nodosum beds in intertidal zones using spot imagery. Hydrobiologia 260/261, 297-305.

Jenkins S.R., Hawkins S.J. and Norton T.A. (1999a) Direct and indirect effects of a macroalgal canopy and limpet grazing in structuring a sheltered inter-tidal community. Marine Ecology Progress Series 188, $81-92$.

Jenkins S.R., Norton T.A. and Hawkins S.J. (1999b) Interactions between canopy forming algae in the eulittoral zone of sheltered rocky shores on the Isle of Man. Journal of the Marine Biological Association of the United Kingdom 79, 341-349.

Kelly L., Collier L., Costello M.J., Diver M., McGarvey S., Kraan S., Morrissey J. and Guiry M.D. (2001) Impact assessment of hand and mechanical harvesting of Ascophyllum nodosum on regeneration and biodiversity. Marine Institute, Dublin, No. 19, 51 pp.

Kendall M.A. and Lewis J.R. (1986) Temporal and spatial patterns in the recruitment of Gibbula umbilicalis. Hydrobiologia 142, 15-22.

Keser M., Swenarton J.T. and Foertch J.F. (2005) Effects of thermal input and climate change on growth of Ascophyllum nodosum (Fucales, Phaeophyceae) in eastern Long Island Sound (USA). Journal of Sea Research 54, 211-220. 
Lazo M.L. and Chapman A.R.O. (1996) Effects of harvesting on Ascophyllum nodosum (L.) Le Jol. (Fucales, Phaeophyta): a demographic approach. Journal of Applied Phycology 8, 87-103.

Le Roux A. (2005) Les patelles et la régression des algues brunes dans le Morbihan. Penn ar Bed 192, 1-22.

Legendre P. and Legendre L. (1998) Numerical ecology. 2nd English edition. Amsterdam: Elsevier Science B.V.

Masterson P., Arenas F., Thompson R.C. and Jenkins S.R. (2008) Interaction of top-down and bottom-up control factors in intertidal rockpools: effects on early successional macroalgal community composition, abundance and productivity. Journal of Experimental Marine Biology and Ecology 363, 12-20.

Menge B.A., Daley B.D., Wheeler P.A., Dahlhoff E., Sanford E. and Strub P.T. (1997) Benthic-pelagic links and rocky intertidal communities: bottom-up effects on top-down control. Proceedings of the National Academy of Science of the United States of America 94, $14,530-14,535$.

Middelburg J.J., Duarte C.M. and Gattuso J.-P. (2005) Respiration in coastal benthic communities. In del Giorgio P.A. and Williams G.A. (eds) Respiration in aquatic ecosystems. Oxford: Oxford University Press, pp. 206-224.

Munda I.M. (1987) Distribution and use of some economically important seaweeds in Iceland. Hydrobiologia 151/152, 257-260.

Scherrer B. (1984) Biostatistique. Québec: Gaëtan Morin.

Smith S.V. (1981) Marine macrophytes as a global carbon sink. Science $211,838-840$.

Soneira A. and Niell F.X. (1975) Sobre la biología de Ascophyllum nodosum (L.) Le Jolis en Galicia. I. Distribución y abundancia en la ría de Vigo. Investigaciones Pesqueras 39, 43-59.
Ugarte R.A., Sharp G.J. and Moore H.B. (2006) Changes in the brown seaweed Ascophyllum nodosum (L.) Le Jol. Plant morphology and biomass produced by cutter rake harvests in southern New Brunswick, Canada. Journal of Applied Phycology 18, 351-359.

Underwood A.J. (1973) Studies on zonation of intertidal prosobranch molluscs in the Plymouth region. Journal of Animal Ecology 42, $353-372$.

Vadas R.L., Wright W.A. and Beal B.F. (2004) Biomass and productivity of intertidal rockweeds (Ascophyllum nodosum Le Jolis) in Cobscook Bay. Northeastern Naturalist 11, 123-142.

Viejo R.M. and Aberg P. (2003) Temporal and spatial variation in the density of mobile epifauna and grazing damage in the seaweed Ascophyllum nodosum. Marine Biology 142, 1229-1241.

Warner G.F. (1984) Dynamic stability in two contrasting epibenthic communities. In Gibbs P.E. (ed.) 19th European Marine Biology Symposium, Plymouth, 16-21 September 1984. Cambridge: Cambridge University Press, pp. 401-411.

Watson D.C. and Norton T.A. (1987) The habitat and feeding preferences of Littorina obtusata (L.) and L. mariae Sacchi et Rastelli. Journal of Experimental Marine Biology and Ecology 112, 61-72.

and

Williams G.A. (1995) Maintenance of zonation patterns in two species of flat periwinkle, Littorina obtusata and L. mariae. Hydrobiologia 309, $143-150$.

\section{Correspondence should be addressed to:} C. Golléty Department of Zoology, University College Dublin Belfield, Dublin 4, Ireland email: claire.gollety@ucd.ie 